\title{
Meaning-creation, selfhood, and religion: From religious metanarratives to spiritual self-narratives
}

\author{
Paulo Jesus \\ Universidade Lusófona do Porto / Universidade de Lisboa
}

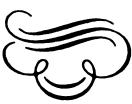

Abstract

This paper attempts to support the idea that the psychology of religion might be developed as an applied branch of cultural psychology. The scope of the argument is both theoretical and empirical. On the one hand, it is argued that religion functions as the most powerful semiotic system which provides subjects with metaphors, narrative frameworks, rituals and other cultural resources for personalised meaning-construction and life-designing. On the other hand, it is illustrated with an exploratory qualitative study bow a specific type of community, a Catholic Seminary, produces a particular set of religious symbols and how their members write their narrative identities in multiple and unstable ways through dialectical tensions and creative self-invention. Thus, the psychology of religion becomes a fruitful laboratory to further investigate the mutually generative interplay between culture and self in order to better understand the plastic process of continuous self-identity formation and transformation.

Keywords: Narrative identity, religious vocation, cultural psychology, Catholic Seminary.

\section{Significado-creación, individualización y religión: desde las metanarrativas religiosas a las autonarrativas espirituales}

\begin{abstract}
Resumen
Este artículo pretende defender la idea de que la psicología de la religión puede desarrollarse como una rama aplicada de la psicología cultural. El ámbito del argumento es tanto teórico como empírico. Por una parte, se razona que la religión funciona como el más poderoso sistema semiótico, que proporciona metáforas, marcos narrativos, rituales y otros recursos culturales a los sujetos para facilitar una construcción del significado personalizada y diseño de vida. Por otra parte, se ilustra con un estudio exploratorio cualitativo cómo un tipo específico de comunidad, un Seminario Católico, produce un conjunto específico de símbolos religiosos y cómo sus miembros escriben sus identidades narrativas de maneras diversas e inestables a través de la tensión dialéctica y autoinvención creativa. Así la psicología de la religión se convierte en un fructífero laboratorio para investigar más a fondo la interacción mutuamente generativa entre la cultura y el individuo con el fin de comprender mejor el proceso plástico de formación y transformación continuo de la identidad propia.

Palabras clave: Identidad narrativa, vocación religiosa, psicología cultural, Seminario Católico.
\end{abstract}

Acknowledgments: The present research was partly funded by the Portuguese Ministry of Science (FCT/MCTES).

The author expresses his sincere gratitude to all people and institutions that made possible this pioneer research. Their hospitality and generosity provided it with large space and time.

Autbor's Address: Escola de Psicologia da Universidade Lusófona do Porto. Rua Augusto Rosa 24, 4000-098 Porto, Portugal.E-mail: paulorenatus@gmail.com 


\section{Estudios de Psicología, 2011, 32 (1), pp. 131-145}

\section{Toward a Cultural Psychology Of Religious Experience}

Cultural psychology aims at elucidating the generation, transmission, appropriation and use of diverse semiotic means that constitute diverse life forms. In contrast with crosscultural psychology, whose main goal resides in "the critical and comparative study of cultural effects on human psychology" (Shiraev \& Levy, 2009, p. 2), presupposing necessarily at least two samples of culturally different subjects, cultural psychology focuses on the dynamic process of meaning-construction in which self and culture merge together, and therefore the analysis of a single subject or a single community suffices to fulfil its epistemological vocation, that is to say, to grasp the organic structure and efficacy of an intentional symbolic world of embodied representations and practices. In other words, and to quote a widely celebrated definition, "Cultural Psychology is the study of the ways subject and object, self and other, psyche and culture, person and context, figure and ground, practitioner and practice, live together, require each other, and dynamically, dialectically, and jointly make each other up" (Shweder, 1990, p. 2). Now, given that religion and spirituality provide subjects with powerful practical grammars, conveying very compelling cultural means for production and organization of thought, emotion and action, one could expect that the field of cultural psychology of religion would have already become a vibrant area of research. And yet, surprisingly enough, one must realize the existence of a double neglect.

Indeed, the lack of effort to integrate both realms in a systematic research program remains evident, not only from the part of cultural psychology but also from the part of psychology of religion. The latter has not adopted a consistent cultural approach to the psychological study of religious and/or spiritual phenomena. Take as an example the fact that Wulff's (1997) encyclopaedic handbook does not identify any "cultural turn", despite the recognition of theoretical pluralism in the field and despite the announcement of the eventual emergence of a "postmodern psychology of religion" (pp. 10-12) with a clear culturalist orientation. Moreover, even when the "need for meaning" or "the search for meaning" is considered as an epistemological "framework", and placed, consequently, at the heart of a renewed and reunited Psychology of Religion (Hood, Hill, \& Spilka, 2009, pp. 12-20), it is still the case that the emphasis on the individual, cognitive and motivational, dimension of meaning-making (including, namely, attributional patterns, need for control and need to belong) seem to overturn the strength of a sociocultural process through which any individual semiotic practices emerge as such. It follows that the individual is still construed as an autonomous actor that has recourse to the usage and consumption of religious meaning-systems to satisfy her needs, as though those meanings were an external toolbox filled with lifeless semiotic objects (whereas it is very likely that the formation of the "tools" as well as that of the "minds and hands" which work with them belong both to the same evolutionary and developmental history). Likewise, the crucial question as to whether and how the very subjective needs are generated, structured, aroused and satisfied by the cultural processes of meaning-making has not been examined at all. For, from this angle, self and culture are often conceived as qualitatively heterogeneous: self would be the actor and culture the bare stage. By doing this, however, the unified essence of the drama fails to be understood.

The unfolding of a drama encompasses the half-scripted and half-spontaneous process of experiencing and expressing the inner life of symbols staged on a very concrete ecological and dialogical space, space which $I$ learn to call my self. On my enacting them, my at once stereotyped and improvised self gains a singular figure. In the drama, symbols and selves read and write unceasingly each other. As they prove psychologically efficacious or true, symbols write selves and, conversely, selves internalize their experience by re-reading and re-writing symbols. The uniqueness of 
"my" experiential matter imposes then a "working-through" - a semiotic Durcharbeitung -, which sheds new light on the strength and weakness of the symbolic means. And, what is more, my working-through vivifies and enlarges the metasemiotic self-consciousness, and finally demands for transgressional and inventive selfinterpretation. Thanks to this self-questioning semiotic workshop, symbols are injected with a power of permanent self-organization and with a high degree of alogical or neological liberty.

The circular flow of co-creation and communal development between self and culture in the lively writing of a singular life story can only be grasped through a psychological lens centred on the full-fledged unity of history, culture, institutions, social relationships and subjective experience, all blended together in virtually infinite ways under the guise of those relational beings we call selves (Gergen, 1992, 1994, 2009). So far, cultural psychology has paradoxically conceded no privilege whatsoever to the analysis of religion, although that might offer an excellent laboratory to investigate the psychosocial life of meaning. It is noteworthy, in effect, that religion is practically absent or appears solely at the margins of most major works in Cultural Psychology (e.g., see Berry, Poortinga, Segall, \& Dasen, 2002; Cole, 1996; Kitayama \& Cohen, 2010; Matsumoto, 2001; Nisbett, 2004; Sam \& Berry, 2006; Shiraev \& Levy, 2009; Stigler, Shweder, \& Herdt, 1990; Valsiner, 2007; Valsiner \& Rosa, 2007).

In this context, it is high time to venture into a new kind of Psychology of Religion devoted to the relational process of meaning-creation, a process which makes possible the very configuration of selfhood. Such Cultural Psychology of Religion would be an applied branch of Cultural Psychology, but this "application" could claim a vantage status among other possible concurrent applied branches, in the sense that religious or spiritual meanings and practices concern the semiotic hard core of selfhood which translates into the formation and assessment of the value of existence itself as well as of the symbolic stance of any possible self in the all-encompassing horizon of meaningful being and becoming. Entering the cycle of ultimate meaning-making, the "modern man", in Jung's (1931, p. 74) sense of the expression, that is to say, the one who is "conscious to a superlative degree", seems to inhabit a ground zero where all rigid meaning systems have been detonated. However, even if Jung's diagnosis is right, pointing to the inability of modern man to cognitive naivveté, it remains true that the modern ruin of stable, self-contained, belief structures, is more strongly linked to the over-exposure to cultural complexity, thick semiotic diversity, and saturation of sociocognitive tensions, than to the overcoming of an "infantile helplessness" (Freud, 1927) or to the defensive suppression of the motivational drive for self-integration and self-actualization (Maslow, 1964). Psychology should neither prognose nor diagnose the future defeat or triumph of religion, because it is not entitled to claim any privileged access to the "truth" of religion. In this respect, Freud (1927) and Lacan (2005) are both utterly loss in their exacerbated desire of Besserverstehen. That is why all (meta)psychology of contemporary religious belief and spiritual quest should embrace epistemic humility, and yield to the intersection of mind and culture, soul and symbol, in the endless life of meaning-making, before embarking on the grandiose identification of in-depth quasi-universal processes.

The qualitative variety of "religious experience" (James, 1902) and of its developmental cycle (Fowler, 1981) must be always regarded as embedded in a sociocultural ecology. Thus, the existential and religious self-questioning of modern western man, marked by a massive trend to deinstitutionalization, must be placed under the large horizon of the social loss of memory that goes hand in hand with the replacement of institutional and communal validation of faith by self-validation, grounded no longer in authoritative conformity nor in group coherence, but in subjective certainty taken as final warrant of truth and salvation (Hervieu-Léger, 2000, 2001). This general outlook is perfectly in line with the current expressivist cultural 


\section{Estudios de Psicología, 2011, 32 (1), pp. 131-145}

ethos of an "age of mobilization and authenticity" where the regulative category of the "true self" constitutes the most valuable narrative framework (Taylor, 2002, pp. 80-87; 2007 , pp. 423-504). Interestingly enough, the quasi-heroic enterprise of finding and accomplishing the "true self" happens to be an inexorable expectation and constraint imposed on the very symbol of "being and becoming oneself". The true self appears then as a spiritual self-made man, and finding that true self has become the main organizer of "identity texts" (Harré, 1989, 1995). The seeming loyalty to oneself is a reply to the cultural categorical imperative of creativity and is interwoven with a maximal cultural complexity and creolization in which every symbol is of mixed origin (Hannerz, 1992). The social loss of memory gives rise to this delusional imperative of self-creation; for it carries with itself the obliteration of the genealogical and hermeneutic chain that links together a body of living signs and practices managed by historical institutions. Under this anhistorical immediacy, the religious self-identity illustrates eloquently the contemporary cultural condition of semiotic saturation and experimentalism through exploratory decoupage, montage, and collage of symbols belonging to historically heterogeneous, if not fully irreconcilable, meaning-systems (Gergen, 1992).

The increasingly personalized semiotic trajectories of religious life are no longer intelligible under the categories of "conversion" and "deconversion", unless they are interpreted as mutually interpenetrated processes of semiotic appropriation and renewal in which every subject oscillates constantly between the multiple modes and combinations of religious self-questioning, overlapping belief and unbelief. The dynamics of the personal spiritual venture, one's continuous openness to Becoming, one's strenuous way along which I am in pursuit of "Self" with a prefigured sense of "truth", "beauty", "unity" and "happiness", consists first and foremost in the inner life of psychologically efficacious symbols, whose activation and operation produce that very dynamics, although they only occur in the workshop of a discursive and performative mind. The religious self has been freed from the strictures of "tradition" by the multiplicity of heterodoxies and the complexity of dissent. Thus, as a posttraditional construction, self becomes a "reflexive project" in a "reflexive culture" (Giddens, 1976, 1991) that invites all social sciences and also the psychology of religion to adopt reflexivity and self-hermeneutics as a methodological device.

The idea of a Cultural Psychology of Religion comprises a Psychology of "becoming religious" understood as a developmentally-sensitive, descriptive science, devoted to the study of a complex overlapping between symbolic systems, social institutions, and personal experiences (see the affinity with the original epistemological stance of Vergote, 1987). Its descriptiveness derives from the ontological agnosticism, or "methodological exclusion of transcendence" (Flournoy, 1903), and from the theoretical assumption of a dynamic, and mutually generative, co-primacy between culture, personal relationships and selfhood in religious life. For "Religion" means a relational process that connects the self to the Possibility or Impossibility of a wholeness of higher meaning for all being (be it conceived as someone, like a "God", or something, like the "divinity", the "sacred" and the "holiness", or just bare Nothingness), and creates a specific form of life which integrates this relational process as a defining ground and horizon.

\section{Selfhood as Meaning-Creation: Drama, Myth, and Poiesis}

Our prospective understanding of a Cultural Psychology of Religion draws inspiration from theoretical work developed by sociocultural psychology on the structure and dynamics of sign use or semiotically mediated action, specially some research based on the fruitful rediscovery of C. S. Peirce, J. M. Baldwin, G. H. Mead, L. S. Vygotsky, and M. M. Bakhtin's works (e.g., Hermans \& Hermans-Konopka, 
2010; Hermans \& Kempen, 1993; Valsiner, 2007; Valsiner \& Rosa, 2007; Wertsch, 1991, 1998, 2002, 2009), and from micro-sociological and anthropological research attentive to the fusion between semiotic practices and the production of selfhood (e.g., among other, Goffman, 1959, 1961; Tomkins, 1987; Turner, 1975, 1995; Turner \& Turner, 1995).

Deprived of an absolute dramaturgical power, every personal self emerges in the middle of an ongoing open drama. The course of this drama overflows with meanings that present diverse degrees of unification and fragmentation, as they organize themselves in presumptive holistic mythologies or rather in local, non-systemic, metaphors. According to their position and function in the semantic architecture to which they belong, those meanings vary greatly in rigidity or stability, in plasticity or mutability, and in logical entailment and modularity. In addition, they also show different modes of interconnectedness whose strength depends on their mutual cohesion, consistency and the ability to dialectically absorb polarized tensions. So, drama is animated and punctuated by multiple strata of embodied myths. In other words, there is no purely spontaneous dramatic action, proceeding from a burst of a purely free agency. Instead, every action embedded in drama involves the enaction or performance of efficacious signs to such an extent that all dramatic spontaneity entails semiotic innovation. Drama and myth cannot be dissociated: drama without myth is brute, meaningless movement, pertaining to the realm of non-human mechanics, and, by the same token, myth without drama is nothing but a naked corpse of dead signs (like a religion without believers).

Not only are drama and myth interdependent but they also have an essential, albeit differential, impact on each other: myth gives structure and meaningful morphology to human action, converting it into a drama, whereas the social play constitutes the performative expression of myth and, by the same token, makes it efficacious for real selves and enriches it with new significant variations. The multilayered semantics of living meaning-systems can be expressed dramatically in various ways, namely by means of ideologically polyphonic characters, or of multiple storylines with their unique space-time frames (or, in Bakhtin's terms, "chronotopes") in part articulated, or intimately imbricate and overlapping, and in part conflicting, or even contradictory. Now, the dramatic actors inject at least some degree of concrete uniqueness in their mythic enaction, which results, to a greater or lesser extent, in a radical autopoietic effect that reshapes the course of the drama and the content of the myth. In sum, meaningful experience implies drama, myth, and poiesis (the latter implying also semiosis, that is, the re-creation of signs or the change of the symbolic order inhabited and embodied by relationally entangled selves).

Selfhood is not a simple carrier of meaning, it is rather the always ephemeral and unstable constellation of signs, organizing themselves in accordance with a unique and dynamic pattern or style of meaning-assimilation and meaning-transformation that produces unpredictable novelty and chaos. In keeping with the idea that the major cognitive, emotional and social organization of selfhood and personhood is executed through storytelling, the study of religious or spiritual selves should favor the analysis of self-narratives (Sarbin, 1986; as to the new semiotic personality psychology, see McAdams, 1996, 1997, 2001, 2005). If the cultural psychology of religion acknowledges the narrative nature of personality and meaning (as well as of selfhood conceived as the realm of reflexive meaning-construction), then the narrative modes of epigenetic formation, personal construction and self-interpretation of religious identities must become its core issue.

The narrative study of lives to be carried out by the cultural psychology of religion could begin by applying in a more analytical vein various fruitful concepts from philosophical descriptions of personhood and from other psychological and sociocultural accounts of identity construction. Among those concepts, we would 


\section{Estudios de Psicología, 2011, 32 (1), pp. 131-145}

emphasize the importance of what P. Ricoeur (1983, pp. 93-104) terms "threefold mimesis" which comprises: "mimesis I" or narrative "pre-figuration", one's embeddedness in stories that pre-organize or pre-structure the hermeneutic horizon and the logical space of possible self-understanding; "mimesis II" or narrative "configuration", the dialogical and discursive process of emplotment that gives narrative form to experience and selfconsciousness; and "mimesis III" or narrative "refiguration", the fusion between the self-as-storyteller and the self-as-tale, which results in my being accountable as the protagonist and proto-narrator of a story (MacIntyre, 1985, pp. 216-218). By virtue of this triple mimesis, the life story becomes a mixture of autobiographical memory and productive imagination to such an extent that the narrated and narrating self can be called a living metaphor, a personal myth or a mythbiography in which "truth" means a sense of subjective self-fidelity, instead of actual historical accuracy (see, v.g., Dilthey, 1911; Freeman, 1993, 2003, 2010; McAdams, 1997, 2005; Passerini, 1990; Ricoeur, 1975, 1983, 1984, 1985, 1990; Spence, 1982).

The cultural psychology of religion might concentrate particularly on the dialectical connections between metanarratives and self-narratives, between reading and writing (in line with the efficacy of the "Quixotic principle", defined by Levin, 1979), between semiotic reproduction and ideological and performative innovation. The exploratory study that follows aims at illustrating the dynamic architecture of those intimate connections in a very specific "total institution" (Goffman, 1961), the Catholic Seminary.

\section{Exploratory Qualitative Study: "Vocation” between Metanarratives and Self- Narratives}

In order to study the semiotic function and psychosocial efficacy of the metaphor of "God's Calling" in the development of self-identity, we have decided to launch a qualitative research project involving direct observation, semi-structured narrative, and group discussion, with almost one hundred subjects who were attending Catholic Seminaries in Portugal (some research data were already presented in Jesus, 2008). The main goal has consisted in describing the appropriation of the Christian metalanguage or metanarrative of "vocation" and assessing the psychological intensity and significance of orthodoxy and heterodoxy, that is to say, of ideological submission and transgression, and relate those semiotic positionings with the subjects' self-narrative patterns. The recognition that "vocation" means at once an ideological identity text (encompassing the general worldview according to which "being oneself" must be a response to God's will) and a narrative schema (connecting, in a spiral way, episodes of revelation and moments of uncertainty, leading gradually to the disclosure of God's will with respect to the self) require the hermeneutic combination of personal ideologies and life stories. Likewise, taking into consideration that vocational mythbiographies, like any other mythbiography, are anchored in ecological and dialogical processes, in institutional and communal practices, we have attempted to distinguish and characterize the diverse layers of social semiotic relationships that organize the particular communitarian life forms typical at Roman Catholic Diocesan Seminaries in the later 1990's and early years of the 21st century in Portugal, a historically and sociologically Roman Catholic country.

\section{Methods}

The most significant methodological feature lies in the qualitative approach (i.e., collection of phenomenological data, containing self-narrative and self-interpretive accounts, associated with the description and evaluation of the spiritual import of priesthood within the Roman Catholic Church in general and of their experience as 
seminarians in particular) and in the cross-sequential design (i.e., a three-year followup of various cohorts in order to contrast and articulate the ontogenesis of vocational identity with the differential generational effects).

\section{Subjects}

With the authorization and collaboration of their superiors, the Seminarians of two Minor and Major Seminaries were invited to participate, on a fully free and voluntary basis, in a psychological research on "vocational stories" for three years in a row. The sample was cumulatively composed of 97 subjects of whom only 33 have volunteered to be followed up (26 participated twice and 8 were interviewed three times). So that full anonymity could be safeguarded at all times in their written accounts, they were asked to use pseudonyms and save it for future occasions. Their ages range from 15 (attending the first year of high school) to 26 (attending the sixth year of theological studies), distributed as shown in table I.

TABLE I

Distribution of Seminarians according to educational level (note that numbers within square brackets refer to the subjects invited to participate; numbers without brackets mean the actual respondents; and numbers within round brackets indicate the quantity of interviewees who have participated in successive data collection). In order to identify the position of the subject in this institutional course, the quotations of their interviews will be followed by a simplified notation of their educational level (i.e., HS 1, HS 2, HS 3, NY, Theo 1-6) and a serial number signaling their location within that cohort of respondents

\begin{tabular}{lllll}
\hline \multicolumn{5}{c}{ Moments of Data Collection } \\
\hline Educational Level & Year 1 & Year 2 & Year 3 & TOTAL \\
\hline High School 1 & {$[12] 4$} & {$[10] 5$} & {$[7] 3$} & {$[29]$ 12 (0) } \\
\hline High School 2 & {$[7] 3$} & {$[8] 2(2)$} & {$[6] 4(4)$} & {$[21]$ (6) } \\
\hline High School 3 & {$[5] 2$} & {$[4] 3(3)$} & {$[4] 2(2)$} & {$[13] 7(5)$} \\
\hline "Null Year” & {$[12] 10$} & {$[15] 11(1)$} & {$[13] 10(2)$} & {$[40] 31(3)$} \\
\hline Theology 1 & {$[9] 7$} & {$[8] 6(6)$} & {$[10] 8(7)$} & {$[27] 21(13)$} \\
\hline Theology 2 & {$[5] 2$} & {$[6] 1(1)$} & {$[4] 3(3)$} & {$[15] 6(4)$} \\
\hline Theology 3 & {$[3] 1$} & {$[4] 0$} & {$[3] 0$} & {$[10] 1(0)$} \\
\hline Theology 4 & {$[3] 0$} & {$[2] 0$} & {$[3] 0$} & {$[8] 0(0)$} \\
\hline Theology 5 & {$[3] 2$} & {$[2] 0$} & {$[3] 1$} & {$[8] 3$} \\
\hline Theology 6 & {$[3] 3$} & {$[2] 2(2)$} & {$[2] 2$} & {$[7] 7(2)$} \\
\hline TOTAL & {$[62] 34$} & {$[61] 30(15)$} & {$[55] 33(18)$} & {$[178] 97(33)$} \\
\hline
\end{tabular}

Strikingly, this distribution of subjects shows a strong asymmetry with psychological significance. There is a sharp concentration of respondents in the extremities and, above all, around the termed "null year" which consists in a Diocesan version of the "novitiate" experience, a year without formal curricular activities devoted solely to spiritual development and vocational growth, at individual and community level. Because most respondents are situated in the threshold zones of their epigenetic 


\section{Estudios de Psicología, 2011, 32 (1), pp. 131-145}

landscape, one may hold that the sample is, therefore, a motivation-biased one. Indeed, as highlighted by classical anthropological studies on liminal experiences (Turner, 1969; van Gennep, 1909), the crossing of any symbolic thresholds in semiotically saturated settings implies the institutional assignation and psychosocial assumption of new self-identities. Now, one could daresay that the Seminary experience as a whole constitutes a ten-year identity threshold, although such threshold presents a nonhomogeneous structure - as it were a threshold with multiple thresholds. The thickest area of the long threshold is to be found in the transition between the Minor and Major Seminary (coinciding with the "null year") as well as at the beginning and end of both cycles. Those transitional moments are exceptionally demanding from the standpoint of meaning-construction; for they decide the specific mode and depth of belonging to the social institutional symbolic life. Instability and exploration are very intense then, and that is why the subjects engage more openly and cooperatively in narrative self-reflection.

\section{Instruments}

Taking into account several narrative interview protocols and guidelines (e.g., Atkinson, 2007; Chase, 2005; Josselson, 1996, pp. 262-272; McAdams, 1997), we have elaborated a semi-structured interview that allows both written and oral administration, though the former mode of application was adopted for practical reasons. Additionally, at the end of each school year, over the three-year period, the participants were invited to a public group discussion on the very experience of being research subjects in that context. The standardized interview addressed the following issues: overall life story, defining episodes, future desirable possible selves, personal ideology (including the concept of "God", "vocation", and "ideal priest"). The analytical lenses we have used while interpreting these qualitative data focus on the following dimensions: the unity and multiplicity of narrative voices, the degree of connectedness (in temporal, causal, and thematic terms), the harmony and conflict between self-interpretations, the submissive reproduction and creative production of religious narrative self-schemata and ideological self-constructs, the differences between subjects according to cohort, and the lines of change in narrative self-identity within subjects over time (Ammerman, 2003; Habermas \& de Silveira, 2008; Habermas, Ehlert-Lerche \& de Silveira, 2009; Leone, 2004; Negele \& Habermas, 2010; Raggat, 2006).

\section{Results}

\section{The efficacy of the institutional framework}

A Seminary is a self-contained social world that creates strong symbolic cohesion and a sense of community based on ideological communion, shared routines and mutual care (described in theological terms as koinonia, leitourgia, and diakonia). For a neutral outsider, it is a very disciplined and structured environment, a resident Catholic school for young men, where all activities (ranging from academic and religious to sporting, artistic and recreational ones) are practically prearranged and take place intra muros at fixed times and places. From the point of view of a faithful insider, it is called "home" and "family"; and, hence, the institutional structuration of life is not regarded as an external constraint, limitation of freedom, but rather as an internalized rule that has become a duty to perform. The rhythm of daily life is set by regular moments of community prayer, including "Liturgy of the Hours", Mass, and shorter prayers introducing and closing every meal, class or meeting. One of the eldest and surest interviewees refers to this structure in a very revealing way, putting it in the broader context of the "vocational adventure": 
My final purpose in life is the unity with God. As many mystics say: happiness is to will His will, to think His thoughts, to feel His feelings. ... The adventure of listening to Him and answering with my life requires a continuous connection, and the Seminary is well designed for that. All my life here gravitates around Him, for "vocation" is a life style in which one is in continuous connection with Him. Whatever I do in my daily life, playing soccer or reading the Bible, everything has the same fundamental meaning: to be one with God. (Theo 6: 3)

Myth and ritual are perfectly interwoven in this community life. Nevertheless, there are multiple possibilities of evaluating and valuing it, of investing it with affect and, therefore, transforming it into one's own life. There are, thus, degrees and modes of perceiving significance and nonsense in that conjunction of myth and ritual; and thence derive the contrastive possibilities of vocational faith, anxiety and irony that shape the self-definition process and flesh it out.

\section{Narrative faith and irony}

In this institutional context, the communal construction and validation of vocational identities presupposes a learning process of acculturation that fosters the internalization of the vocational metanarrative. Its ideological and narratological structure proceeds from the Biblical prototypic vocational narratives. As Martini (2006) and Ricoeur (1988) reconstruct and analyze those paradigmatic stories of Calling and Following, the subject attains gradually, even painstakingly, a deep transformation and renewal of his self-understanding through a spiritual path of careful reading and interpretation of "signs" and "ordeals". The metanarrative schema of the Vocation encompasses: 1. a foundational event, a first Calling that takes the subject unawares; 2. a state of perplexity, doubt, fear and bewilderment that imposes on him the need for an interpreter and counselor; 3. a series of ordeals that put him to the test and are accompanied by hidden signs that confirm the truth of the Calling; 4 . public selftransformation or conversion (in the double sense of metanoia, change of mind, and epistrophe, change of direction in life), entailing faithful commitment to a higher mission. The elements 2 to 4 are not necessarily successive; they may coincide in time and reinforce each other in a circular way.

Let us consider different self-narrative summaries of different age groups, and let us note the general recurrence of the same structure with some evaluative variations regarding the subjective sense of "story closure versus story openness" in congruence with the degree of vocational commitment or exploration, certainty or doubt:

I come from a non-observant family, practically non-Christian. ... I recall vividly that one day, on the Sunday school, I felt something strange, a strong desire to be like a disciple or apostle of Christ, relive those extraordinary events. ... I had many problems when I decided to enter the Seminary. ... I have fought against everything with the help of my parish priest and my grandmother. Thanks to them I may attend the Seminary in order to find out my vocation. ... God wants to make a story with me and I want to live it to the fullest. (HS 1:2)

When I was born I did not know what vocation had been reserved to me, and even now... I cannot tell yet. ... Nothing special happened in my childhood. There was, however, a very striking moment in all my life. ... A priest came to my village and asked to a group of young boys: Who would like to be a priest? Nobody answered. Nobody would like to be so. Then, suddenly, they all pointed to me and said: Him. Very embarrassed, I could do nothing but reply instantly and defensively: Me, never! The truth is that the idea penetrated me deeply. I went to talk with my Sunday school teacher who explained to me how to apply to the Seminary. I took the admission tests and here I am. CONFUSED. (HS 2:1)

When I was a kid, maybe five years old, I was already pondering entering a religious community. ... As I grew up in contact with peers, I left that ideal behind. ... When I was 12 years old I was invited by a priest to visit the Seminary. But the fear of being rejected by others, by the society, did not allow me to accept the invitation. ... Afterwards, during the military service, that idea was again totally repressed. ... Then, I had my first job and the desire of being priest was frequently in my mind. ... People around me would say that I had vocation, even my boss. ... Eventually, my family also gave me total freedom to follow this path and here I am, thanks goodness. (NY: 1) 
It is always difficult to read our bistory, especially when you invest yourself in the task of unveiling vocational signs that point the way of your vocation. Indeed, vocation entails mystery. It is the mystery of Him who, being God, wants to take part in your "poor existence" and share His life. (Theo 2: 3)

The narrative schema of Vocation is so well established in the minds of the seminarians that they feel lost when their lives seem refractory to that normative reading. When the goodness of fit between experience and "myth" is jeopardized, the subject suffers a crisis of self-intelligibility. In a way, the strength of the desire of belonging to the God's Story is so imposing in its absoluteness and Truth, that if it is frustrated, it provokes a deep feeling of self-estrangement. See a telling example of such disquieting situation:

I feel something very strange. Whereas others know quite well their vocational stories and can recall the key events that had impact on their vocation, I myself, however strange it may be, I cannot recall anything of that. I cannot say when and how I began feeling the desire to be a priest. ... All I can say is that I have always had an inclination to things related with the Church. ... It does seem as though my entering the Seminary was determined from my conception. (HS 1: 5)

The psychological paradox of the narrative schema of Vocation uncovers the theology of Vocation that underlies it and constitutes an "identity text" which articulates freedom and pre-determination. Using Marcia’s (1966) vocabulary, one may affirm that the vocational adventure mediated by the Seminary experience promotes identity achievement by acculturating a metanarrative according to which the best selfexploration consists in self-foreclosure and self-surrender to a superior, and yet innermost, Voice. For this Voice is believed to be the most truthful expression of the deepest nature of myself. If the subject adheres consistently to this view, there will be nothing alienating in his theonomous obedience. Quite the opposite, God's Voice becomes the royal access to an unknown and absolute inner truth. This notion of God's intimacy, a theological metapsychology, echoes in their theology of vocation and gives rise to an effortful attempt to fully reconcile autonomy and theonomy, self-disclosure and God's disclosure, self-actualization and self-abandonment, eudemonism and theocentrism. But the theological metanarrative of inborn vocation (as theonomous and, what is more, ecclesionomous autonomy) clashes with the modern metanarrative of bounded subjectivity as a self-sufficient center of spontaneity, which corresponds also to the metanarrative of selfhood in contemporary mainstream psychology. Now, most Seminarians are profoundly exposed to both metanarratives and vow loyalty to both. Vocational dissonance and anxiety are, therefore, often intensely aroused in their quest for a synthesis:

\footnotetext{
Vocation is something born within a human being, something you feel and make you choose a lifestyle. Some get married, others keep celibacy, all should be equally happy. (HS 1: 6)

Vocation is a Calling made by God in order for us to be His children and to be happy. God wants our happiness, for He loves us. (HS 1: 7)

Vocation is to be called to fulfill a function within a given community. ... It is a pathway defined by God and that we must follow freely. (HS 2: 1)

By vocation I understand a kind of personal "destiny", in which lies the secret of your happiness. Everyone is born with a vocation which constitutes the only way you can follow in your future to secure as much happiness as possible. It is also something bidden that must be discovered and pondered. (HS 3:2)

Vocation is neither a profession nor a job. It is God's choice. (HS 3: 3)

To my mind, vocation is a calling and also a will of the called. ... Vocation is the possession of skills. ... I may feel called to become a priest as a result of my personal will becoming consonant with God's will. (NY: 5)

Vocation is the personal way of belonging to the Church. No one is entitled to decide individually; it requires others' advice, guidance and even approbation for a final decision. (Theo 1:2)

Vocation is the progressive adjustment of my will to God's will with respect to myself. (Theo 1: 3)

Vocation is to plunge into God, for He calls everyone by their name. Undoubtedly, it is a calling but a calling that must entail a reply and a mission - as St. John says "As the Father sent me, I also send you" (Jo 20, 21). Vocation
} 
is God's gift and I think that the fundamental thing is that a vocation be a service, a complete self-gift to the other and to the community. (Theo 5: 1)

According to their theology of vocation, God's "signs" are very often veiled and ambiguous, and may demand - and usually do demand - the recourse to an experienced interpreter. In this respect, the Seminary provides them not only with the right environment to learn the Christian "myth" of Vocation but also with the social resources to engage in joint self-interpretation. No one can here legitimately self-validate his story as an authentic Calling. There is an authoritative and hierarchical institution that supplies spiritual guidance and helps the subject read the mysterious divine semiology. Roman Catholic ecclesiology is of paramount importance to understand the mediated nature of the interpretive process of supposedly vocational "signs": the Church is "sacrament of salvation". This entails that the "true self" of a faithful believer that feels called must freely, autonomously, accept two kinds of responsiveness and receptivity, one theological and other ecclesiological. The Roman Catholic believer who interprets himself "under the voice of Calling" does not yield solely to an autonomous theonomy. He must place himself in a triadic system in which theonomy, the highest destiny of autonomy, is accessed through ecclesionomy. It follows an ambivalent double erosion of agency, marked by the theological value of conformity to God's voice (and to its institutional mediation) because God's disclosure brings the full disclosure of the "convoked self". The selfactualization of this proactively obedient self is accomplished thanks to an attitude of selflessness, full availability and openness to be astounded by the Voice that reveals my self to my self. For the self is not the agent of the process. Nor does he own the space where meaning is constituted. In a sense, nolens volens, the self endures the event of Calling; it happens to him who is attentive and welcoming.

Two extreme opposite experiences may present themselves, proving the abovementioned ambivalence. On the one hand, such self-dispossession would mean existential self-gift and be held as the most valuable experience in life, unconditional trust in God's goodness and in His truthful historical institutional interpreters (that is, autonomy in harmonious concert with "theo-ecclesio-nomy"). On the other hand, it can be lived as sacrifice, mutilation, and self-loss. The interviewees seem to be acutely divided by this ambivalence, trying to reconcile the three concurrent voices of their spiritual life-designing, that is to say, autonomy, ecclesionomy and theonomy. Various modes of polyphonic harmony and disharmony become, then, self-evident within and between subjects. Irony expresses the global awareness of that inner polyphony but it also has multiple faces depending on the differential "power relations" between competitive voices and/or metanarratives. As we understand it, "irony" embodies a meta-cognitive and meta-identity status that evaluates the quality, pace and direction of change in self-identity.

Irony can be termed "faithful" or "orthodox irony" when the converted self complies with the Calling (criticizing his past selves from a theonomous and ecclesionomous perspective); "critical" or "heterodox irony" when the prophetic self questions the coherence of the Institution that interprets the Calling (putting ecclesionomy in jeopardy, denying the legitimacy of its mediation, for God's sake); "diffused" or "unstable irony" when a nihilistic self has skeptically suspended his belief in any higher criterion of evaluation (thus approaching axiological anomy and spiritual agnosticism). There is no normative sequential order whatsoever in the chaining of ironic attitudes. Each type of irony makes absolute sense per se and may constitute a stable position for indefinite time. All trajectories prove to be possible and meaningful, although psychoand theo-logically incommensurate. Let us observe and analyze briefly some occurrences of different types of irony and ironical trajectories. Firstly, notice the confirmatory trajectory of self-interpretation within "orthodox irony", with a strong change of focus, from an individual quasi-heroic view: 


\section{Estudios de Psicología, 2011, 32 (1), pp. 131-145}

Then I asked myself: Why not me? And I said: My life is in Your hands. ... I only need a sign to see clearly Your will. ... My application was not accepted by the University. ... For me, it was God's sign. Was it really or not? ... I felt more seduced by the idea of having a family, a job, etc. And yet I had the strength to overcome many seductions, sacrifices and privations till the present commitment. Otherwise I could not. ... I have succeeded in my pursuit of truth and happiness. (Theo 5: 1)

To a relational and holistic one that dominates his account one year later, only months before ordination:

I owe my becoming a priest to many people. It is a huge beautiful mosaic where my new face emerges with their presence and support - specially my mother's unconditional love. (Theo 6: 4)

Secondly, let us note the transition from orthodox to heterodox irony. The appropriation of a self-image dominated by Calling induces a "hindsight bias" that devaluates the past life which seems non-pertinent to build such storyline:

The story of my life has nothing extraordinary. Like any life, however, it is original in its singularity. ... I recall my past as void of significance till I understood my way. Now, I feel completely free to decide. If I embrace priesthood - and I hope so and God as well apparently -, I will do it freely and happily. (Theo 1: 3)

From this "orthodox irony", rewriting the past through a vocational reconstruction of it, he will develop a special kind of "heterodox irony" that emphasizes social and cognitive detachment from the Church. Indeed, in the following year, the same subject declares:

I live poisoned with empty concepts, bypocritical attitudes, and false gestures. Or maybe my eyes see it because they are poisoned. [...] The essential thing is neither to belong to the 'machine' of the Church nor to master a dogmatic system, but to serve God and Humankind. (Theo 2: 1)

Take still other examples of "heterodox irony", described as awakening experiences, unleashing the refusal of homogeneity and the claim for accountability:

To be priest means to be father of everyone. In the Seminary very few things fascinate me. What disturbs me the most is the cynicism and hypocrisy that exist sometimes. ... The ideal priest: mature, beard, barefoot. Signs of poverty, wisdom and devotion. (HS 2: 1)

My opinion about priests is increasingly negative. ... Very often they are not a good example, being too much focused on their image and well-being. ... I went through the application process without being fully aware of the consequences. Then I was accepted. At first I did not know what I should do but afterwards I was pushed by the stream and six years later here I am. ... 'To be or not to be' - that's my question. (HS 3: 2)

My current vocational situation is very fragile owing to spending many years [9 years] in several Seminaries. This is how I interpret my vocational reality. I feel more and more undecided about the way to follow. There are no significant people in my story. Jesus Christ is the only one. (Theo 3: 4)

Thirdly, consider the opposite ways that heterodox irony may follow. If there is institutional assimilation of "heterodox irony", the "dissident" may become a "religious hero" or a "moral exemplar" (see McDonough, 2010). In contrast, in case of institutional resistance to the free and constructive practice of self-criticism, some of the most zealous and authentic members, those who share critical concerns about the fidelity to original values, are excluded and their "heterodox irony" may turn easily into "empty self-questioning". Once deprived of mutually valued belongingness, "heterodox irony" is on the verge of "diffused irony":

To my mind, vocation is something one discovers over time and eventually one becomes sure of his own will. ... At this point, it is very difficult to tell my story and say bow I have discovered my vocation - if this 'stuff exists at all - because I am leaving! For this reason, I cannot answer. (HS 3: 7)

In the last analysis, the nihilistic irony encourages muteness and defiance, as in the excerpt below full of contempt towards the "researcher" and the possibility of reciprocal trust and interest: 
I have no time to write about me. It is almost 11 pm. It is time to switch off the lights. I have not used the blank sheets of paper because they were precious to do other things. ... I appreciate your work very much, but the questions are beyond my understanding! (HS 3: 6)

The narrative schema is thus entirely dissolved. Only for the "unstable ironist" is it true that truth has no canon. Caught in the crossfire between metanarratives, the unstable ironist takes refuge in the desert of incredulity (Lyotard, 1979/1984: xxiv-xxv; Rorty, 1989). But this "irony" is also a robust form of self-articulacy that supposes the learning of a "language game" and acculturation into a "form of life" (Wittgenstein, 1953), composed of liquid attachments with vaporous choices and counter-choices in spiritual self-narratives (Bauman, 2003, 2005).

\section{Conclusion}

As we view it, the Cultural Psychology of Religion would allow us to grasp how a semiotic system (e.g., "Vocation") encloses multiple potentialities and how its efficacy in shaping real lives accomplishes multiple actualities.

As a double-edged sword, the identity text of "vocation" may have strong but dramatically opposed effects. It places the subject in the midst of ideological tensions and existential dilemmas that correlate with the institutional organization of meaningmaking. In effect, the rigidity of this theological and moral metanarrative, as is socially enacted within the Roman Catholic Church, creates very cohesive in-group ties among the subjects who manage to rewrite coherently themselves, providing them with robust certainties. But, whenever a subject persists in any form of counterinstitutional (or counter-symbolic) self-questioning, even in name of a radically purer "christomorphism", he is prone either to intense anxiety or existential fear or selfdissociation (see Beier, 2009; Drewermann, 1989, 2009; Ranke-Heinemann, 1992). The process of vocational development embraces subjective semiosis within an institutional system of contrivances and opportunities in which the ideological organization of practices gives a common anchorage to selves in movement - from symbol to symbol.

\section{References}

Ammerman, N. T. (2003). Religious identities and religious institutions. In M. Dillon (Ed.), Handbook of the Sociology of Religion (pp. 207-224). Cambridge: Cambridge University Press.

Atkinson, R. (2007). The Life Story Interview as a Bridge in Narrative Inquiry. In J. Clandinin (Ed.), Handbook of Narrative Inquiry: Mapping a Methodology (pp. 224-245). Thousand Oaks, CA: Sage.

Bauman, Z. (2003). Liquid Love. Cambridge: Polity Press.

Bauman, Z. (2005). Liquid Life. Cambridge: Polity Press.

Beier, Matthias (2009). Gott ohne Angst: Einführung in das Denken Drewermanns. Ostfildern: Patmos.

Berry, J. W., Poortinga, Y. H., Segall, M. H., \& Dasen, P. R. (Eds.) (2002). Cross-Cultural Psychology: Research and Applications. Cambridge: Cambridge University Press.

Chase, S. (2005). Narrative Inquiry: Multiple Lenses, Approaches, Voices. In N. Denzin \& Y. Lincoln (Eds.), The Sage Handbook of Qualitative Research 3rd ed (pp. 651-679). Thousand Oaks, CA: Sage.

Cole, M. (1996). Cultural Psychology: A Once and Future Discipline. Cambridge, MA: Harvard University Press.

Dilthey, W. (1911/2002) Selected Works (R. A. Makkreel and F. Rodi, Eds.): Vol. 3, The Formation of the Historical World in the Human Sciences. Princeton, NJ: Princeton University Press.

DrewermanN, E. (1989/2010). Kleriker: Psychogramm eines Ideal. Neu-Isenburg: Melzer Verlag.

Drewermann, E. (2009). Heilende Religion: Überwindung der Angst (hersg. von J. Kunstmann). Freiburg i.B.: Herder.

Flournoy, T. (1903). Les principes de la psychologie religieuse. Archives de Psychologie, 2, 33-57.

Fowler, J. W. (1981). Stages of Faith: The Psychology of Human Development and the Quest for Meaning. New York: Harper One. FreEman, M. (1993). Rewriting the Self: History, Memory, and Narrative. London: Routledge.

FrEEMAN, M. (2003). Rethinking the fictive, reclaiming the real: Autobiography, narrative time, and the burden of truth. In G. Fireman, T. McVay, Jr., \& O. Flanagan (Eds.), Narrative and Consciousness: Literature, Psychology, and the Brain (pp. 115-128). New York: Oxford University Press.

Freeman, M. (2010). Hindsight: The Promise and Peril of Looking Backward. New York: Oxford University Press.

Freud, S. (1927/1961). The Future of an Illusion. In Standard Edition (Vol. 21, pp. 1-56). London: Hogarth Press.

Gergen, K. J. (1992/2000). The Saturated Self: Dilemmas of Identity in Contemporary Life. New York: Basic Books.

Gergen, K. (1994). Realities and Relationships: Soundings in Social Construction. Cambridge, MA: Harvard University Press.

Gergen, K. (2009). Relational Being: Beyond Self and Community. New York: Oxford University Press.

Giddens, A. (1976). New Rules of Sociological Method: A Positive Critique of Interpretative Sociologies. London: Hutchinson. 


\section{Estudios de Psicología, 2011, 32 (1), pp. 131-145}

GIDDENS, A. (1991). Modernity and Self-Identity: Self and Society in the Late Modern Age. Cambridge: Polity.

Goffman, E. (1959). The Presentation of Self in Everyday Life. New York: Anchor Press.

Goffman, E. (1961). Asylums: Essays on the Social Situation of Mental Patients and Other Inmates. New York: Anchor Press.

Habermas, T., \& De Silveira, C. (2008). The development of global coherence in life narratives across adolescence: Temporal, causal, and thematic aspects. Developmental Psychology, 44, 707-721.

Habermas, T., Ehlert-Lerche, S., \& De Silveira, C. (2009). The development of the temporal macrostructure of life narratives across adolescence: Beginnings, linear narrative form, and endings. Journal of Personality, 77, 527-560.

Hannerz, U. (1992). Cultural Complexity: Studies in the Social Organization of Meaning. New York: Columbia University Press.

Harré, R. (1989). Language Games and the Texts of Identity. In J. Shotter \& K. J. Gergen (Eds.), Texts of Identity (pp. 2035). London: Sage.

HARRÉ, R. (1995). Discursive Psychology. In J. A. Smith, R. Harré \& K. van Langenhove (Eds.), Rethinking Psychology (pp. 95-121). London: Sage.

Hermans, H. \& Hermans-Konopka, A. (2010). Dialogical Self Theory: Positioning and Counter-Positioning in a Globalizing Society. Cambridge: Cambridge University Press.

Hermans, H. \& Kempen, H. (1993). The Dialogical Self: Meaning as Movement. New York: Academic Press.

Hervieu-Léger, D. (2000). Religion and Memory. New Brunswick, NJ: Polity Press.

HERVIEU-LÉGER, D. (2001). Individualism and the validation of faith. In R. K. Fenn (Ed.), Sociology of Religion (pp. 161-175). Oxford: Blackwell.

Hood, JR, R. W.; HiLl, P. C., \& SPILKA, B. (2009). The Psychology of Religion: An Empirical Approach. New York: Guilford Press.

JAMES, W. (1902/1985). Varieties of Religion Experience: A Study in Human Nature. Cambridge, MA: Harvard University Press.

Jesus, P. (2008). Self-generative anxiety and irony: Unstable religious life-narratives. Paper presented at The Fifth Conference on the Dialogical Self (Cambridge, UK, August 26-29th, 2008).

Josselson, R. (1996). Revising Herself: The Story of Women's Identity from College to Midlife. New York: Oxford University Press.

Jung, C. G. (1931/1969). The Spiritual Problem of Modern Man. In Collected Works (vol. 10, pp. 74-94). Princeton: Princeton University Press.

Kitayama, S. \& Cohen, D. (Eds.) (2010). Handbook of Cultural Psycbology. New York: Guilford Press.

LACAN, J. (2005). Triomphe de la religion précédé de Discours aux catholiques. Paris: Seuil.

LeONe, M. (2004). Religious Conversion and Identity: The Semiotic Analysis of Texts. London: Routledge.

Levin, H. (1979). The Quixotic Principle. In M. W. Bloomfield (Ed.), The Interpretation of Narrative: Theory and Practice (pp. 45-66). Cambridge, MA: Harvard University Press.

Lyotard, J.-F. (1979/1984). The Postmodern Condition: A Report on Knowledge. Minneapolis: University of Minnesota Press. MacInTYRE, A. (1985). After Virtue: A Study in Moral Theory. London: Duckworth.

MARCIA, J. E. (1966). Development and Validation of Ego Identity Status. Journal of Personality and Social Psychology, 3, 551 558

Martini, C. M. (2006). La Vocación en la Biblia. Salamanca: Sígueme Ediciones.

MAsLow, A. H. (1964). Religions, Values, and Peak-Experiences. New York: Harper.

Matsumoto, D. (Ed.) (2001). The Handbook of Culture and Psychology. New York: Oxford University Press.

MCADAMs, D. P. (1996). Personality, modernity, and the storied self: A contemporary framework for studying persons. Psychological Inquiry, 7, 295-321.

McAdams, D. P. (1997). The Stories We Live By: Personal Myths and the Making of the Self. New York: Guilford Press.

McADAms, D. P. (2001). The psychology of life stories. Review of General Psychology, 5, 100-122.

McADAms, D. P. (2005). The Redemptive Self: Stories American Live By. New York: Oxford University Press.

McDonough, G. P. (2010). Why dissent is a vital concept in moral education. Journal of Moral Education, 39 (4), 421-436.

Negele, A., \& Habermas, T. (2010). Self-Continuity Across Developmental Change in and of Repeated Life Narratives. In K. McLean \& M. Pasupathi (Eds.), Narrative Development in Adolescence: Creating the Storied Self (pp. 1-21). New York: Springer.

NisBETT, R. (2004). The Geography of Thought: How Asians and Westerners Think Differently... and Why. New York: Free Press.

Passerini, L. (1990). Mythbiography in oral history. In R. Samuel \& P. Thompson (Eds.), The Myths We Live By (pp. 4960). London: Routledge.

RaggatT, P. (2006). Multiplicity and Conflict in the Dialogical Self: A Life-Narrative Approach. In D. P. McAdams, R. Josselson, \& A. Lieblich (Eds.), Identity and Story: Creating Self in Narrative (pp. 15-35). Washington, DC: APA.

Ranke-HeinemanN, U. (1992/2004). Nein und Amen: Mein Abscbied vom traditionellen Christentum. München: W. Heyne.

Ricoeur, P. (1975). La métaphore vive. Paris: Seuil.

Ricoeur, P. (1983). Temps et récit 1: L'intrigue et le récit historique. Paris: Seuil.

Ricoeur, P. (1984). Temps et récit 2: La configuration dans le récit de fiction. Paris: Seuil.

Ricoeur, P. (1985). Temps et récit 3: Le temps raconté. Paris: Seuil.

Ricoeur, P. (1988). Le sujet convoqué : A l'école des vocations prophétiques. Revue de l'Institut catholique de Paris, 28, 83-99.

RicoeuR, P. (1990). Soi-même comme un autre. Paris: Seuil.

RORTY, R. (1989). Contingency, Irony and Solidarity. Cambridge: Cambridge University Press.

SAM, D. L., \& Berry, J. W. (Eds.) (2006). The Cambridge Handbook of Acculturation Psychology. Cambridge: Cambridge University Press.

SARbIN, TH. R. (1986). The Narrative as a Root Metaphor for Psychology. In Th. R. Sarbin (Ed.), Narrative Psychology: The Storied Nature of Human Conduct (pp. 3-21). New York: Praeger.

Shweder, R. A. (1990). Cultural Psychology - What Is It? In J. Stigler, R. Shweder, \& G. Herdt (Eds.), Cultural Psychology: Essays on Comparative Human Development (pp. 2-43). Cambridge: Cambridge University Press.

Shiraev, E. B., \& LeVY, D. A. (2009). Cross-Cultural Psychology: Critical Thinking and Contemporary Applications (4th Edition). Boston: Allyn \& Bacon.

SPENCE, D. P. (1982). Narrative Truth and Historical Truth: Meaning and Interpretation in Psychoanalysis. New York: Norton.

TomkINs, S. S. (1987). Script theory. In J. Aranoff, A. Rabin, \& R. Zucker (Eds.), The Emergence of Personality (p. 147-216). New York: Springer.

TuRNER, V. (1969/1995). The Ritual Process: Structure and Anti-Structure. New York: Aldine Transaction.

Turner, V. (1975). Dramas, Fields, and Metaphors: Symbolic Action in Human Society. Ithaca, NY: Cornell University Press. 
Turner, V., \& Turner, E. (1995). Image and Pilgrimage in Christian Culture. New York: Columbia University Press. VALSINER, J. (2007). Culture in Minds and Societies: Foundations of Cultural Psychology. London: Sage.

Valsiner, J. \& Rosa, A. (Eds.) (2007). The Cambridge Handbook of Socio-Cultural Psychology. New York: Cambridge University Press.

Van GenneP, A. (1909/1961). Rites of Passage. Chicago: Chicago University Press.

Vergote, A. (1987). Religion, foi, incroyance: Etude psychologique. Bruxelles: P. Mardaga.

Wertsch, J. (1991). Voices of the Mind: A Sociocultural Approach to Mediated Action. Cambridge, MA: Harvard University Press. Wertsch, J. (1998). Mind as Action. New York: Oxford University Press.

Wertsch, J. (2002). Voices of Collective Remembering. New York: Cambridge University Press.

Wertsch, J. (2009). Collective memory. In P. Boyer \& J. Wertsch (Eds.), Memory in Mind and Culture (pp. 117-137). Cambridge: Cambridge University Press.

Wittgenstein, L. (1953). Philosophical Investigations. Oxford: Basil Blackwell.

WulfF, D. M. (1997). Psychology of Religion: Classic and Contemporary. New York: J. Wiley. 